\title{
Rekonstruksi Pendidikan Islam Multikultural Indonesia Perspektif Filsafat Pendidikan Islam
}

\author{
Ali Ismunadi, ${ }^{1}$ Moh. Faisal Khusni ${ }^{2}$ \\ ${ }^{1}$ Sekolah Tinggi Ilmu Ekonomi Ar-Rachman Batam, Indonesia \\ ${ }^{2}$ Universitas Islam Malang, Indonesia \\ Iabadzulfi12@gmail.com, 2chusnifaishol@gmail.com
}

\begin{abstract}
Efforts to explore various basic principles and ideals of Islamic education have become exciting studies in the discourse on Islamic philosophy. This study is even more interesting when juxtaposed with contemporary lessons such as multiculturalism and Islam Nusantara. Ironically, this discourse has stagnated in academic debate. In this context, the researcher uses a literature study approach by examining primary sources in the Islamic philosophical thought family. This research aims to see the philosophical basis with dimensions, principles, norms, and values that live and use as human guidance. In this study, the researcher finds that from the perspective of Islamic philosophy, the basis of multiculturalism base on the Islamic doctrine of Rahmatallil'alamin. The common goal in the formation of humans is perfect humans as servants of Allah, social beings, and part of the universe. This basic principle is relevant to apply to humans in Indonesia who are diverse in culture, ethnicity, and religion.
\end{abstract}

Keywords: Islamic philosophy, Multiculturalism, insan kamil, Islam Nusantara

\begin{abstract}
Abstrak
Usaha mendalami berbagai prinsip pokok dan idealisme pendidikan Islam mmenjadi kajian menarik dalam diskursus di filsafat Islam. Kajian ini semakin menarik jika disandingkan dengan diskursus kontemporer seperti multikulturalisme dan Islam Nusantara. Ironisnya, diskursus ini mengalami kemandegan dalam perdebatan akademik. Dalam konteks inilah, peneliti menggunakan pendekatan studi pustaka dengan mengkaji sumber-sumber primer dalam rumpun pemikiran filsafat Islam. Tujuan penelitian ini, untuk melihat basis filoshofis yang berdimensi, prinsip, norma dan nilai-nilai yang hidup dan dijadikan pantuan manusia. Dalam konteks kajian ini, peneliti menemukan dalam kaca mata filsafat Islam, basis multikulturalisme harus dilandaskan pada doktrin Islam Rahmatallil'alamin. Kesamaan tujuan dalam pembentukan manusia adalah manusia sempurna sebagai hamba Allah, makhluk sosial, dan bagian dari alam semesta. Prinsip mendasar inilah yang sangat relevan diterapkan pada manusia di Indonesia yang ragam budaya, suku dan agama.
\end{abstract}

Kata kunci: Filsafat Islam, Multikulturalisme, Insan kamil, Islam Nusantara

\section{Pendahuluan}

Selama ini, pendidikan seringkali hanya dimaknai sebagai transfer of knowledge dari orang yang mengerti kepada yang belum mengerti. ${ }^{1}$ Padahal, tujuan pendidikan lebih luas dari sekedar transfer pengetahuan. Sebagian dari tujuan pendidikan adalah di samping untuk keberhasilan individu, juga adalah untuk keadaban sebuah bangsa. ${ }^{2} \mathrm{Di}$

\footnotetext{
${ }^{1}$ Syaiful Anwar, Desain Pendidikan Agama Islam; Konsepsi dan Aplikasinya dalam Pembelajaran di Sekolah (Yogyakarta: Idea Press Yogyakarta, 2014), 20.

${ }^{2}$ Anwar, 20.
}

Tribakti: Jurnal Pemikiran Keislaman

Volume 32, Nomor 2, Juli 2021 
sinilah pemikiran filosofis yang radikal-universal diperlukan untuk membedah problem pendidikan Islam yang berarti menyelami masalah apa pun dalam hubungannya dengan keseluruhan secara radikal, mulai dasar-dasarnya hingga konsekuensi-konsekuensinya. ${ }^{3}$

Sebagai bagian dari kebutuhuan yang diperlukan manusia yang sifatnya personal dan juga komunal, pendidikan berfungsi sebagai bimbingan, sarana pertumbuhan yang sadar dan sistematis agar manusia dapat hidup secara manusiawi dalam segala dimensi kehidupannya. Pendidikan sebagai transmisi memanusiakan manusia dapat dilaksanakan dalam bentuk informal, formal, maupun nonformal. Untuk memenuhi kebutuhan tersebut, sejak berupa ide, konsep dan langkah implementasi pendidikan harus senantiasa mengandung pemikiran dan solusi yang mampu memecahkan problematika yang dihadapi umat manusia, menyesuaikan dengan perkembangan zaman yang ada dan siap menghadapi tantangan zaman yang senantiasa muncul.

Oleh karena itu, dengan filsafat pendidikan, proses menganalisis, mengkritik, bahkan mendekonstruksi segala kemapanan dalam pendidikan perlu untuk terus tumbuh. Lebih jauh, filsafat pendidikan Islam sebagai suatu analisis atau pemikiran rasional yang dilakukan secara kritis, radikal, sistematis, dan metodologis diperlukan guna menghasilkan pemahaman mendalam tentang hakikat pendidikan Islam. ${ }^{4}$ Dalam penjelasan yang diberikan oleh Abuddin Nata, Filsafat Pendidikan Islam adalah sebuah aktifitas berpikir atau kegiatan menyeluruh yang berupaya menemukan konsep, pengetahuan, menyelenggarakan dan/ atau memecahkan beragam permasalahan pendidikan Islam melalui kajian yang mendalam pada kandungan nilai-nilai dan makna dalam al-Qur'an, al-Sunnah serta berbagai cabang ilmu keislaman yang pondasinya telah dirancang oleh para sarjana Muslim (ulama). ${ }^{5}$

Di sisi lain, dalam konteks Indonesia, filsafat Islam juga sangat penting untuk didialogkan dengan isu pendidikan multikulturalisme. Kajian ini sebagai bahan untuk melakukan refleksi secara ilmiah tentang norma dan norma panduan hidup manusia. Pertanyaan mendasar peneliti, bagaimana paradigma filsafat Islam melihat pendidikan multikulturalisme dan implementasi Islam rahmatal ill'alamin pada lembaga pendidikan Islam.

${ }^{3}$ M.J. Langeveld, Menuju Kepemikiran Filsafat, terjemahan oleh G.J. Claessen (Jakarta: P.T. Pembangunan, t.t.), 10; Murthadha Muthahhari, Belajar Konsep Logika, terjemahan oleh Ibrahim Husein Al Habsyi, (ogyakarta: Rausyanfikr Institute, 2013), xiii.

${ }^{4}$ Abdul Munir Mulkan, Paradigma Intelektual Muslim: Pengantar Pendidikan Islam dan Dakwah (Yogyakarta: SIRPRESS, 1993), 74.

${ }^{5}$ Abudin Nata, Filsafat Pendidikan Islam (Jakarta: Logos, 1997), 15. 
Berdasarkan konteks tersebut memahami manusia, perannya dan upaya yang harus dilakukan guna membantu keberhasilan manusia Islam dalam melaksanakan tugasnya melalui pisau bedah filsafat pendidikan Islam menjadi kebutuhan yang mendesak. Apalagi dalam konteks Indonesia negara yang multikultural dan multireligius terbesar di dunia.

\section{Metode}

Penelitian ini merupakan jenis penelitian kepustakaan (library research), di mana penelitian ini didasarkan pada sumber-sumber kepustakaan berupa buku-buku dan penelitian-penelitian yang mengangkat permasalahan filsafat pendidikan Islam multikultural. Data yang diorganisir melalui proses pengumpulan, membaca, mengolah dan menganalisis data tersebut menjadi data sebuah yang dapat disajikan dan disimpulkan.

Dikarenakan permasalahan penelitian yang diangkat adalah permasalahan filosofis (filosofi pendidikan), maka untuk menguraikan permasalahan tersebut digunakan pendekatan filosofis.Yang dimaksud pendekatan filosofis yaitu sarana untuk menguji dan menyusun data yang diperlukan bagi penjelasan terhadap filosofi pendidikan. Sebagaimana yang diketengahkan Henderson:

"..As Scientists it is their business, to invent techniques, to device means. In contrast, it is the business of philosophy, as it is of religion, to help mankind of to decide how such discoveries should be used, indeed to decide upon those ends toward the realization of which all scientific facts and knowledge of techniques ought to be used as means, for philosophy does concern itself with values and with what ought to be as well as what it is." 6

Rasionalisasi pada pendekatan filosofis ini menggunakan pendekatan konseptual dan pendekatan kritis. Pendekatan konseptual-kontekstual yang dimaksud yaitu mencoba memahami filsafat pendidikan Islam multikultural yang tidak terlepas dari konteks sosial, politik, budaya dan sebagainya di mana permasalahan pendidikan Islam multikultural berada. Pendekatan konseptual-kontekstual ini bermaksud menjelaskan situasi-situasi dan perkembangan-perkembangan suatu proses pendidikan Islam multikultural yang muncul pada penelitian-penelitian terdahulu.

\footnotetext{
${ }^{6}$ Stella Van Petten Henderson, Introduction to Philosophy of Education (Chicago: The University of Chicago Press, 1974), 6-7.

Tribakti: Jurnal Pemikiran Keislaman

Volume 32, Nomor 1, Juli 2021
} 
Kemudian pada pendekatan kritis didasarkan pada argumen tekstual dan kontekstual memiliki tiga ciri utama yaitu, pertama kajian filosofis selalu terarah pada fundamental ideas terhadap penelitian yang sedang dikaji, kedua perumusan ide-ide dasar dapat menciptakan critical thought, ketiga kajian filsafat pendidikan yang demikian dapat membentuk mentalitas dan kepribadian yang mengutamakan intellectual freedom sehingga terbebas dari dogmatism dan fanatisme. ${ }^{7}$

Setelah data terkumpul maka proses selanjutnya adalah analisis data. Analisis data dengan mengorganisasikan data, memilah-milahnya menjadi satuan yang dapat dikelola, mensintesiskannya, mencari dan menemukan pola, menemukan apa yang penting melalui pemeriksaan secara konsepsional atas makna yang terkandung dalam sumber data.

\section{Hasil dan Pembahasan}

\section{Tantangan Islam: Permenungan Filosofis}

Persoalan yang tidak mudah untuk dikaji umat Islam salah satunya adalah perihal filsafat Islam. Mulai dari sisi pengertiannya saja tidak ditemukan kesepakatan apa itu filsafat Islam. Sayyed Hossein Nasr memberikan penjelasan filsafat Islam merupakan filsafat yang mengambil sumbernya pada al-Qur'an dan al-Hadits. Baginya, hakikat dari filsafat Islam adalah hermeneutika filosofis dari teks sakral yaitu al-Qur'an dengan memanfaatkan khazanah filsafat dari zaman terdahulu. ${ }^{8}$

H. Corbin hampir mirip dengan Nasr, menyebut filsafat Islam dengan filsafat kenabian (la philosophie prophetique) mengingat al-Qur'an dan al-Hadits merupakan dimensi ajaran yang dibawa oleh Nabi Muhammad. Sementara itu, Oliver Leaman memberikan pernyataan kalau filsafat Islam itu tidak terlalu signifikan perbedaannya dengan filsafat. Yang membedakan adalah ia mendapat corak kreatif keislaman akibat tumbuh berkembang dalam lingkungan peradaban Islam. Menurut Fazlur Rahman, filsafat Islam berakar dari aliran filsafat khususnya Yunani yang diberikan unsur agama dalam hal ini Islam ke dalamnya. Filsafat Islam juga dapat dikatakan filsafat umum yang

7 Zulkarnain, Kontekstualisasi Filosofi Pendidikan dalam Sistem Pendidikan Persekolahan (Bandung: Universitas Pendidikan Indonesia, 2011), 160.

${ }^{8}$ Seyyed Hossein Nasr, History of Islamic Philosophy (London and New York: Routlege, 1996), 27. 
berjubah aktual Islam. ${ }^{9}$ Begitulah kutipan-kutipan para cendekiawan tentang filsafat Islam.

Dari sekian banyak disiplin ilmu keislaman, pendidikan Islam adalah filsafat yang di dalamnya dibahas dan dikaji hal-hal yang berhubungan dengan kependidikan Islam. ${ }^{10}$ Beberapa hal pokok terkait dengan pendidikan Islam antara lain:

1. Asas-asas kependidikan yang sumber utamanya yaitu al-Qur'an dan al-Hadits. Landasan pemikiran ini adalah kepercayaan bahwa dalam al-Qur'an dan al-Hadits telah menjawab berbagai macam persoalan kehidupan termasuk di dalamnya masalah pendidikan meskipun pada bagian-baigan pelaksanaannya hanya dibahas secara global. ${ }^{11}$

2. Pokok-pokok konsep kependidikan Islam yang telah disusun rapi oleh para filsuf Muslim dari sisi ontologi bahwa Tuhan, alam dan isinya termasuk manusia adalah bahasan pendidikan Islam yang amat penting. Kemudian dalam epistemologinya menggali lebih dalam metodologi maupun sumber pengetahuan pendidikan Islam. Kajian nilai dalam sistem pendidikan Islam adalah bahasan yang senantiasa dikembangkan dalam aksiologi pendidikan. ${ }^{12}$

3. Pendidikan Islam tidak cukup hanya mengedepankan sisi ilmiah dari aspek idealitas dan sumber dari kitab suci, pendidikan Islam juga harus terus mengaktualisasi dirinya agar terus adaptif terhadap zaman sehingga dapat menjadi rujukan dalam upaya membangun teori pendidikan Islam yang peka zaman. Inilah tuntutan zaman yang selalu berkembang dengan tetap mengedepankan integritas ilmiah seperti terus melakukan riset dan eksperimen. ${ }^{13}$

Berdasarkan 3 (tiga) hal mendasar inilah, pendidikan Islam dapat diandalkan menjawab berbagai tantangan global, seperti problematika kemiskinan yang terstruktur, dampak kerusakan lingkungan yang memengaruhi ekosistem, konflik berlatar SARA, pengabaian nilai kemanusiaan, kesetaraan hukum, dan seterusnya. Jika pendidikan Islam dapat menjawab tantangan ini, maka agama tidak akan melulu berbicara tentang Tuhan (teosentris), tetapi juga

${ }^{9}$ M. Amin Abdullah, Filsafat Islam: Historitas dan Aktualisasi (Yogyakarta: FA Press - ADFI, 2014), iii.

10 Mappasiara, "Filsafat Pendidikan Islam," Jurnal Pendidikan Islam VI (t.t.): 274, https://doi.org/10.24252/ip.v6i2.5231.

${ }^{11}$ Abdul Mujib dan Yusuf Mudzakir, Ilmu Pendidikan Islam (Jakarta: Kencana Premada Media, 2006), 6 .

12 Mappasiara, “Filsafat Pendidikan Islam” VI (2017): 275, https://doi.org/10.24252/ip.v6i2.5231.

13 Abdul Mujib dan Yusuf Mudzakir, Ilmu Pendidikan Islam (Jakarta: Kencana Prenada Media, 2006), 7.

Tribakti: Jurnal Pemikiran Keislaman Volume 32, Nomor 1, Juli 2021 
berhubungan dengan problematika kemanusiaan (antroposentris) yang semakin hari semakin berat. Semangat ini tentu sangat sesuai dengan perintah al-Qur'an yang banyak memberi perhatian dan menjunjung tinggi aspek kemanusiaan.Teologi Islam hari ini tidak boleh hanya terbuai oleh cerita masa lampau, melainkan selalu memahami perubahan yang ada, terlebih pada masa kontemporer seperti saat ini di mana pemikiran manusia terpengaruhi oleh perubahan sosial akibat dari pesatnya perkembangan ilmu pengetahuan dan teknologi. ${ }^{14}$

\section{Basis Filosofis Pendidikan Islam Multikultural}

Pendidikan Islam memiliki tujuan dan prinsip dengan dasar teologi yang menyertainya. Tujuan makro pendidikan Islam adalah menyelematkan dan melindungi fitrah manusia, mengembangkan potensi-potensi fitrah manusia, dan menyelaraskan langkah perjalanan manusia agar sesuai dengan fitrah kemanusiaannya ${ }^{15}$ Dalam Konferensi Pendidikan Islam Internasional pertama tahun 1977 di Saudi Arabia, disimpulkan secara teknis dan praktis tujuan pendidikan Islam berbunyi:

“Tujuan pendidikan Islam adalah menciptakan manusia yang baik dan benar, yang berbakti kepada Allah dalam pengertian yang sebenar-benarnya, serta menumbuhkan kepribadian manusia yang meyeluruh secara seimbang melalui latihan jiwa, intelek, perasaan, fisik dan indera. Karena itu, pendidikan Islam harus mencapai pertumbuhan manusia dalam segala aspeknya: spiritual, intelektual, imajinatif, fisik, ilmiah, bahasa, baik secara individual maupun secara kolektif, dan mendorong semua aspek ini ke arah kebaikan dan mencapai kemaslahatan yang sempurna. Tujuan akhir pendidikan Islam terletak dalam perwujudan kedudukan yang sempurna kepada Allah, baik secara pribadi, komunitas, maupun keseluruhan umat manusia."16

Ada berbagai varian filsafat pendidikan Islam, sebagaimana dirumuskan oleh Muhaimin: ${ }^{17}$ Petama, Modernis. Dalam ontologinya, segala sesuatu yang ada serba berubah sesuai dengan sunnatullah. Sedangkan secara epistemologis, perubahan sosial beserta problematika dan tantangan kehidupan manusia sesuai dengan zamannya, akal dan budi manusia dianggap berguna dan berkualitas apabila mampu beradaptasi terhadap tantangan-tantangan tersebut dengan dilandasi iman dan takwa. Aksiologinya, kebenaran nilai universal mutlak dari Allah, dan pengembangan nilai-nilai instrumental bersifat lokal yang relatif senantiasa menggapai kebenaran tersebut.

${ }^{14}$ Amin Abdullah, Falsafah Kalam di Era Postmodernisme (Yogyakarta: Pustaka Pelajar, 2006), 42.

${ }^{15}$ Muhammad Tholchah Hasan, Dinamika Pemikiran tentang Pendidikan Islam (Jakarta: Lantabora Press, 2006), 37.

${ }^{16}$ Hasan, 37.

${ }^{17}$ Muhaimin, Pengembangan Kurikulum Pendidikan Islam di Sekolah, Madrasah dan Perguruan Tinggi (Jakarta: Raja Grafindo Persada, 2005), 65. 
Kedua, Perenialis-Esensialis Madzhabi. Dalam ontologinya, segala sesuatu sifatnya tidak akan mengalami perubahan dan tetap. Pandangan aliran ini secara epistemologis mengatakan bahwa akal dan budi manusia dianggap berkualitas bila warisan budaya Islam dan nilai tradisi peradaban Islam yang dibawa para leluhur pendahulu dihargai dan memahami keberhasilannya dalam menyelesaikan problematika yang ada dalam sejarahnya. Aksiologinya, para ulama dan filsuf Muslim zaman dahulu adalah generasi yang telah memonopoli penemuan dan juga pencarian nilai kebenaran lokal dan universal atau instrumental. Tugas dari generasi sekarang dan penerus kelak tetap melestarikan dan memelihara meskipun zaman berubah begitu juga situasi dan kondisinya.

Ketiga, Perenial-Esensialis Salafi. Dalam ontologinya, segala yang ada diyakini bersifat tetap, terkecuali pada batas-batas tertentu yang nilai instrumentalnya perlu adanya perubahan. Secara epistemologis, warisan budaya Islam dan nilai tradisi yang dibawa generasi salaf yang terwujud dalam sejarah peradaban Islam, akal dan budi manusia dikatakan bernilai guna bila mampu meletakkan dan menghargainya. Aksiologisnya, monopoli generasi salaf dalam penemuan dan pencarian nilai-nilai kebenaran universal, harus dilestarikan kemudian dipelihara oleh generasi sekarang begitupun penerusnya yang akan datang.

Keempat, Perenial-Esensialis Kontekstual Falsifikatif. Pandangan ontologisnya, segala sesuatu ada yang berubah dan juga ada yang tetap. Akal dan budi manusia dikatakan bermanfaat dan sesuai dengan harapan ketika secara sadar pandangannya terhadap warisan nilai budaya Islam dan tradisi yang dibawa para leluhur termaktub dalam sejarah peradaban Islam mampu dihargainya, kemudian secara konseptual dapat merespon perkembangan zaman baik melalui ilmu pengetahuan teknologi dan juga perubahan sosial. Sementara aksiologisnya, generasi terdahulu telah dan dapat menemukan nilai kebenaran universal, sehingga tidak dikatakan hanya menjadi monopoli generasi penerus. Generasi penerus memiliki tugas untuk terus mencari nilai kebenaran yang belum ditemukan generasi pendahulu, mengembangkannya kemudian melestarikannya dalam konteks ilmu pengetahuan dan perubahan sosial yang ada.

Kelima, Rekonstruksi-Sosial. Pandangan epistemologisnya bahwa akal beserta budi manusia itu kreatif dan telah membuktikan perbedaannya dengan makhluk-makhluk lain yang ada di bumi. Manusia dulu dan sekarang berbeda, dalam kurun seratus tahun terakhir pun terlihat signifikansi perbedaannya beserta perubahan sosial dan ilmu 
pengetahuan teknologi yang mengiringinya, sehingga tuntutan kualitas kehidupan manusia terus berkembang melewati batas budaya. Dalam hal ini post-paradigmatik atau disebut dengan rekonstruksi sosial berkelanjutan perlu dimasukkan dalam filsafat ilmu pendidikan.

Tinjauan metafisik di Indonesia dengan beragam budaya serta bangsa yang ada selalu bertekad dalam keragaman dan persatuan, terbukti dengan semboyannya Bhineka Tunggal Ika. A fair justice dalam keragaman etnik, budaya dan agama mampu membuat overlapping consensus dan menjadi moral hidup yang nilai-nilainya perlu dididik dalam kehidupan nasional dan global. Satu keyakinan universal dan adil, yang baik mendapatkan pahala, berbuat jahat mendapatkan dosa, saling menghargai dan menghormati Tuhan dan surganya masing-masing terdapat dalam tiap-tiap agama di dunia. $^{18}$

Pembahasan lebih jauh dari tipe-tipe pemikiran filsafat pendidikan Islam, bahwa tipe modernis berupaya terhadap pengembangan pendidikan dengan berbagai subjek didiknya sebagai tugas penting yang harus dilakukan secara berkensinambungan, semaksimal mungkin dengan rekonstruksi pengalaman sehingga mampu menyesuaikan dengan segala tuntutan yang ada pada saat ini atau yang akan datang dengan cerdas. Hanya saja tipe pemikiran ini kurang relevan bila diterapkan di Indonesia yang masyarakatnya senantiasa bergotong royong, mengedepankan tanggung jawab bersama dalam mengatasi permasalahan bangsa, karena sifatnya terlalu individualistik dan kurang bermasyarakat dalam aspek tanggung jawab.

Tipe Perenial-Esensialis Madzhabi dan Perenial-Esensialis Salafi dianggap belum tentu mampu dan kurang relevan penerapannya dalam mengatasi problematika pendidikan Islam di Indonesia yang berpandangan ke depan, karena terlalu mengunggulkan pelestarian dan upaya mempertahankan nilai budaya dan warisan peradaban masa lalu. ${ }^{19}$

Tipe yang berusaha menengahi antara pelestarian nilai budaya masa lalu dan modernis adalah tipe Perenial-Esensialis Kontekstual-Falsifikatif yang melihat wawasan kependidikan Islam dikontekstualisasi sekaligus uji falsifikasi perkembangannya bersamaan dengan ilmu pengetahuan teknologi berikut perubahan sosial yang ada. ${ }^{20}$

18 Noeng Muhadjir, Tantangan Pendidikan Islam; Mengintegrasikan Wawasan Islam dan Ilmu Pengetahuan (Yogyakarta: Lembaga Pers dan Mahasiswa UII, 1987), 107-14.

19 Moch. Tolchah, "Filsafat Pendidikan Islam; Konstruksi Tipologis dalam Pengembangan Kurikululm,” Jurnal Peradaban Islam Tsaqafah 2, no. 2 (2015): 396.

${ }^{20}$ Tolchah, 398. 
Sementara itu, tipe Rekonstruksi Sosial berupaya menyelesaikan permasalah pendidikan Islam di Indonesia di masa yang akan datang dengan bersifat antisipatif dan proaktif serta berupaya mengembangkan aspek tanggung jawab individual dan kemasyarakatan sebagai tugas utamanya. Dalam fungsi pendidikannya, tipe ini berupaya menumbuhkan dan mengembangkan peserta didik untuk selalu kreatif dalam menyiapkan tenaga kerja produktif, menambah pengetahuan khazanah budaya manusia dan memperbanyak isi nilai-nilai kemanusiaan. Dapat dikatakan bahwa tugas pendidikan tipe Rekonstruksi Sosial adalah membuat manusia cakap dalam sumber daya serta melibatkan diri dalam pengembangan masyarakatnya. ${ }^{21}$

Manakah dari tipe pemikiran filsafat pendidikan berbasis Islam di atas yang dapat menjadi tolok ukur dalam pengembangan pendidikan Islam multikultural? Menurut Moch. Tolchah, perlu kembali mengkaji dan mendalami paradigma yang terdapat dalam sumber utama Agama Islam, yaitu al-Qur'an dan al-Hadits, juga hasil karya ilmiah para alim ulama dan cendikiawan muslim multidisiplin ilmu dengan tidak mengabaikan proses sejarah peradaban Islam sebagai bahan pengembangan karakter pendidikan Islam yang bentuk penampilannya tidak harus eksklusif dan tidak larut serta dapat memengaruhi sistem yang ada. Karakter tersebut meliputi empat hal pokok. Pertama, ilmu yang diamalkan apapun bentuknya adalah bentuk tanggung jawab manusia kepada Tuhan dan masyarakat disekitarnya. Kedua, semangat dalam thalab al-ilm, menguasai dan mengembangkannya, adalah bagian dari ibadah. Ketiga, pribadi seseorang dengan segala potensi dan kemampuannya diakui dapat selalu berkembang. Keempat, akhlak atau budi

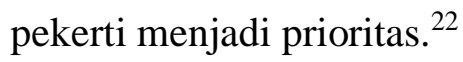

Melihat potensi yang ada di Negara Indonesia dengan segala keragaman dan dasar filosofis negara yang terdapat dalam Pancasila, terutama sila pertama, maka tipologi filsafat pendidikan Islam yang sesuai untuk mengembangankan pendidikan Islam multikultural adalah tipe Rekonsturksi Sosial yang berpedoman pada tauhid. Tauhid merupakan konsep dari sikap teosentris dari sila Ketuhanan Yang Maha Esa, ditempatkan pada sila pertama karena fungsinya sebagai acuan empat sila selanjutnya. ${ }^{23}$

Upaya untuk mewujudkan pendidikan Islam multikultural bercorak Rekonstruksi Sosial belandaskan tauhid, setidaknya, ada enam acuan dasar. Pertama, mendidik peserta didik sehingga mampu berpikir secara kritis. Kedua, mendidik peserta didik agar ketika berhubungan

21 Tolchah, 399.

22 Tolchah, 393.

23 Tolchah, 396.

Tribakti: Jurnal Pemikiran Keislaman

Volume 32, Nomor 1, Juli 2021 
berhubungan dengan masyarakat punya kemampuan berpikir strategis dan bertindak teknis. Ketiga, mendidik peserta didik dalam partisipasinya pada pengembangan dan pembangunan masyakarakat agar mampu bekerja bersama untuk tatanan kehidupan yang lebih baik. Keempat, mendidik peserta didik agar mampu menganalisis problematika kekinian dalam masyarakat sebagai bahan kajian. Kelima, mendidik peserta didik agar kolaboratif dan mampu bekerja dalam tim. Keenam, mendidik peserta didik untuk bersikap toleran dan menghargai segala perbedaan yang ada.

\section{Urgensi Pendidikan Islam Multikultural di Indonesia}

Peneliti berpandangan bahwa tipologi Rekonstruksi Sosial berlandaskan tauhid menjadi pilihan yang tepat untuk kaum muslimin Indonesia mengingat keberagaman Indonesia dalam semua halnya. Manusia Islam Indonesia harus menyadari benar bahwa ia mempunyai tanggung jawab transenden sebagai sebagai konsekuensi manusia bertauhid, tanggung jawal sosial sebagai makhluk sosial dan tanggung jawab kebangsaan sebagai warga bangsa yang penuh warna keberagaman.

Di sinilah pendidikan Islam multikultural dalam konteks Indonesia menjadi sebuah kebutuhan. Di mana proses pendidikan harus mampu menegaskan fitrah sucinya sebagai manusia Islam sekaligus manusia Indonesia yang menghargai dan melestarikan identitas nasionalnya. Dengan demikian Islam Indonesia akan memiliki corak keislaman sendiri, di mana ikatan Islamiyah, wathaniyah dan basyariah menjadi kesatuan yang utuh sebagai wujud Islam rahmat li al-alamin.

Ali Harb berpendapat bahwa Islam inklusif, toleran, akomodatif, apresiatif dan egaliter yang peka terhadap budaya setempat adalah makna dari rahmat li al- 'alamin. ${ }^{24}$ Perwujudannya ada pada kaum Muslimin yang paham pada problem-problem sosial di tengah masyarakat, selalu mengkondisikan suasana dan lingkungan yang aman, tentram, harmonis, dan juga memahami beragam perbedaan yang merupakan sunnat Allah dalam kehidupan di dunia ini.

Pendidikan Islam multikultural pada akhirnya akan menjadi suatu keniscayaan yang memberikan kemampuan pada manusia Islam Indonesia sebagai benteng bangsa dari efek buruk globalisasi pemikiran dan gaya hidup beragam masyarakat dunia yang terus berkembang dan saling berebut pengaruh seperti terlihat dalam perang dagang Amerika dan China. Pendidikan Islam multikultural berusaha mengurangi pengaruh isme dunia tunggal yang

${ }^{24}$ Ali Harb, Nalar Kritis Islam Kontemporer (Yogyakarta: IRCiSoD, 2012), 7. 
melibatkan kutub-kutub yang berbenturan antara Utara-Selatan ataupun Barat-Timur dengan menghubungkan perspektif multipolar dan multikultural. ${ }^{25}$

Multikulturalisme sejalan dengan ajaran Islam, di mana tidak ada perbedaan manusia dalam derajatnya karena etnik, ras dan lain sebagainya kecuali atas keimanannya dan ketakwaannya. Dalam Islam, pendidikan multikultural mencerminkan bagaimana tingginya penghargaan Islam terhadap kemanusiaan, ilmu pengetahuan dan tidak ada dikotomi dalam pembidangan ilmu. Sehingga output dari pendidikan Islam multikultural adalah manusia Islam Indonesia yang siap sebagai hamba Allah yang bertauhid, humanis, dan pelindung nusa dan bangsanya. Manusia Islam Indonesia, tidak boleh hanya saleh secara individual, tetapi ia juga harus saleh secara sosial.

Gambar 1Filsafat Pendidikan Islam Multikultural Indonesia ${ }^{26}$

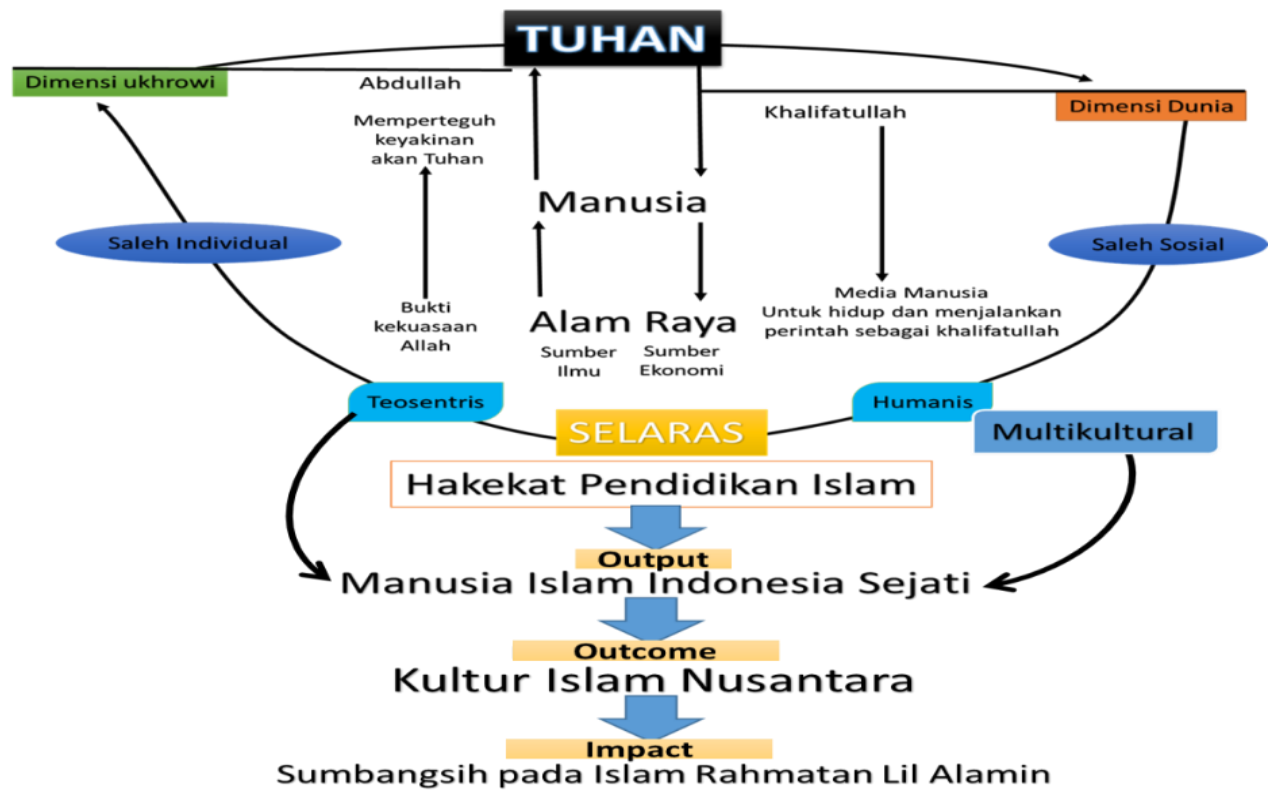

Berdasarkan ilustrasi di atas, bisa dijelaskan bahwa Allah Tuhan semesta alam adalah puncak dan sumber dari segalanya. Manusia sebagai makhluk yang memiliki dua dimensi tugas sebagai hamba Allah sekaligus khalifah Allah yang akan hidup di dua dimensi alam (dunia dan akhirat) dituntut untuk menyempurnakan tugasnya dengan sebaik-baiknya. Di sinilah hakekat tugas pendidikan Islam. Dalam konteks keberagamaan, multikulturalisme menjadi salah satu paham penting yang harus dipedomani sebagai jalan agar proses pendidikan yang dilakukan khususnya di Indonesia tidak kehilangan identitas nasionalnya. Dengan demikian, pada output-

${ }^{25}$ Zakiyuddin Baidhawy, Pendidikan Agama Berwawawasan Multikultural (Jakarta: Erlangga, 2005), 17.

${ }^{26}$ Baidhawy, 20.

Tribakti: Jurnal Pemikiran Keislaman

Volume 32, Nomor 1, Juli 2021 
nya akan melahirkan manusia Islam Indonesia sejati yang berkultur nusantara dan pada akhirnya akan memberi warna dan pengokoh pada tujuan besar Islam rahmat li al-alamin.

Manusia Islam Indonesia tidak boleh hanya sibuk dengan menjadi saleh secara individual sementara lupa substansi atau hakekat perintah atau larangan dalam Islam. Perintah dan larangan Islam sesungguhnya bukan hanya bentuk kepatuhan hamba kepada Tuhannya, akan tetapi memiliki dimensi kemanusiaan yang tinggi. Sebagai contoh perintah untuk berpuasa, sejatinya mengajarkan agar kita bisa memahami kesulitan orang lain sehingga memunculkan sikap bersyukur dan saling tolong-menolong kepada lainnya. Perintah zakat bermakna bahwa di sebagian harta yang kita peroleh, ada hak orang lain yang harus diberikan.

Sebagai salah satu bentuk pembelajaran, kiranya dapat digambarkan sebagai materi pembelajaran dengan berdasarkan ayat kawniyah berupa proses terjadinya hujan. Di mana proses hujan pada awalnya dari penguapan kemudian terjadi kondensasi kemudian turun hujan. Dari turun hujan ini terjadi penyerapan sehingga memungkinkan tanah menyimpan air untuk kebutuhan makhluk hidup sebagai sumber kehidupan. Seterusnya demikian siklus kehidupan.

Dari analogi proses terjadinya hujan di atas dapat dijelaskan hikmah sebagai berikut: Pertama, proses penguapan ke atas dianalogikan sebagi fitrah manusia untuk berTuhan. Setiap manusia cenderung akan mencari zat yang maha agung sebagai bentuk pengakuan akan kebesarannya dan ketundukan. Dalam konteks Islam, Tuhan adalah Allah Azza Wa Jalla (fitrah teosentris). Untuk itu, manusia selalu menunaikan perintah dan larangan dari Tuhan (saleh individual).

Kedua, proses kondensasi atau proses hujan mengisyaratkan bahwa sebagai bentuk kepatuhan kepada Tuhan harus dimanifestasikan dalam bentuk nyata kehidupan. Dalam hal ini bagaimana memberikan rasa teduh, aman, nyaman kepada sesama dengan semangat saling tolong-menolong, memperkuat dan membantu kesuksesan bersama atas nama kemanusiaan (aaleh Sosial). Bertuhan berarti berkemanusiaan karena salah satu dimensi utama agama adalah melindungi kemanusiaan.

Ketiga, saleh individual dan saleh sosial selayaknya dua keping mata uang, di mana agama tanpa kemanusiaan adalah kenestapaan yang paradoks. Ia akan seperti uang bermuka sebelah yang tidak membawa nilai.

Keempat, jika kesalehan individu dan sosial ini terus dipupuk suburkan (proses precipitation/pengendapan), maka akan membawa kuatnya jalinan persaudaraan sesama agama (ukhuwah islamiyah), pesaudaraan kebangsaan (ukhuwah wathaniyah) ,dan 
persaudaraan kemanusiaan universal (ukhuwah basyariah). Dengan demikian, di mana saja seorang Muslim akan selalu menjadi juru damai yang menyuburkan kebaikan.

Kelima, jika ada seorang Muslim mempunyai kesalehan individual yang tinggi tetapi rendah kesalehan sosialnya, maka sungguh tidak memahami hakekat menjalankan perintah atau larangan Islam. Ia seperti awan tanpa hujan yang tidak mampu mendinginkan bumi.

Keenam, Muslim sejati sungguh tidak cukup mencintai perdamaian dan membenci permusuhan, tetapi harus menjadi problem solver yang mampu menjadi seorang peresolusi konflik yang baik dengan mengawali kemampuan mengendalikan dirinya sendiri dan mempunyai kepedulian sosial yang tinggi. Karena dua hal inilah kunci melakukan resolusi konflik.

Ilustrasi dari proses terjadinya hujan tersebut merupakan ayat kawniyah yang seharusnya mampu dibaca dan diamalkan oleh setiap Muslim. Jika saja semua Muslim paham dan mau mengamalkan ini, maka segala perbedaan yang sifatnya sunnat Allah tidak sibuk dicari titik pisahnya, akan tetapi yang diperkuat adalah titik temunya selama tidak bersinggungan dengan persoalan akidah dan ketauhidan kepada Allah Azza Wa Jalla.

\section{Kesimpulan}

Pendidikan selalu berupaya agar peserta didik menjadi manusia dewasa yang memiliki tanggung jawab terhadap diri sendiri dan sekelilingnya dengan bekal nilai, etika, kemandirian, pengetahuan dan akhlak atau budi perkerti bersumberal-Qur'an dan al-Hadits. Sejatinya, hakikat dari pendidikan Islam multikultural merupakan upaya menghasilkan manusia Islam Indonesia yang berwawasan Nusantara dan pembawa misi Islam rahmat li al-alamin. Manusia yang mengabdi kepada Tuhan sepenuhnya (saleh individu) dan melayani kemanusiaan dengan setulusnya (saleh sosial), sungguh selayaknya dua keping dari satu mata uang. Agama tanpa kemanusiaan adalah kenestapaan yang paradoks, sementara kemanusiaan tanpa agama adalah kehampaan yang tak berujung. Agama dan kemanusiaan tidak akan bernilai jika hanya bermuka sebelah.

\section{Daftar Pustaka}

Abdullah, Amin. Falsafah Kalam di Era Postmodernisme. Yogyakarta: Pustaka Pelajar, 2006.

Abdullah, M. Amin. Filsafat Islam: Historitas dan Aktualisasi. Yogyakarta: FA Press ADFI, 2014. 
Anwar, Syaiful. Desain Pendidikan Agama Islam; Konsepsi dan Aplikasinya dalam Pembelajaran di Sekolah. Yogyakarta: Idea Press Yogyakarta, 2014.

Baidhawy, Zakiyuddin. Pendidikan Agama Berwawawasan Multikultural. Jakarta: Erlangga, 2005.

Harb, Ali. Nalar Kritis Islam Kontemporer. Yogyakarta: IRCiSoD, 2012.

Hasan, Muhammad Tholchah. Dinamika Pemikiran tentang Pendidikan Islam. Jakarta: Lantabora Press, 2006.

Henderson, Stella Van Petten. Introduction to Philosophy of Education. Chicago: The University of Chicago Press, 1974.

Langeveld, M.J. Menuju Kepemikiran Filsafat, terjemahan oleh G.J. Claessen. Jakarta: P.T. Pembangunan, t.t.

Mappasiara. "Filsafat Pendidikan Islam" VI https://doi.org/10.24252/ip.v6i2.5231.

—. "Filsafat Pendidikan Islam." Jurnal Pendidikan Islam VI (t.t.). https://doi.org/10.24252/ip.v6i2.5231.

Muhadjir, Noeng. Tantangan Pendidikan Islam; Mengintegrasikan Wawasan Islam dan Ilmu Pengetahuan. Yogyakarta: Lembaga Pers dan Mahasiswa UII, 1987.

Muhaimin. Pengembangan Kurikulum Pendidikan Islam di Sekolah, Madrasah dan Perguruan Tinggi. Jakarta: Raja Grafindo Persada, 2005.

Mujib, Abdul, dan Yusuf Mudzakir. Ilmu Pendidikan Islam. Jakarta: Kencana Premada Media, 2006.

—. Ilmu Pendidikan Islam. Jakarta: Kencana Prenada Media, 2006.

Mulkan, Abdul Munir. Paradigma Intelektual Muslim: Pengantar Pendidikan Islam dan Dakwah. Yogyakarta: SIRPRESS, 1993.

Muthahhari, Murthadha. Belajar Konsep Logika, terjemahan oleh Ibrahim Husein Al Habsyi, Yogyakarta: Rausyanfikr Institute, 2013.

Nasr, Seyyed Hossein. History of Islamic Philosophy. London and New York: Routlege, 1996.

Nata, Abudin. Filsafat Pendidikan Islam. Jakarta: Logos, 1997.

Tolchah, Moch. "Filsafat Pendidikan Islam; Konstruksi Tipologis dalam Pengembangan Kurikululm." Jurnal Peradaban Islam Tsaqafah 2, no. 2 (2015).

Zulkarnain. Kontekstualisasi Filosofi Pendidikan dalam Sistem Pendidikan Persekolahan. Bandung: Universitas Pendidikan Indonesia, 2011. 